\title{
MISTAKE IN AN ELECTRONIC ADVERTISEMENT: LEGAL IMPLICATION
}

\section{Rosmawani Che Hashim}

\author{
Department of Business Strategy and Policy, \\ University of Malaya, Malaysia \\ wanie285@um.edu.my
}

Received: 11 February 2019 Accepted:14 May 2019 Published Online: 24 December 2018

\begin{abstract}
It is fundamental that the content of the advertisement must be free from any disputable errors. Otherwise; the owner of the advertisement shall be liable for customers' claims in regard to its content. Obviously, advertisements, be it traditional or online are exposed to legal repercussion should it fails to comply with the terms as per advertised. This paper discusses the legal implications of such advertisement from a contract law perspective focusing on an electronic advertisement containing price errors. It refers to the area of mistake in contract law and highlights the common law and equitable approaches in dealing with this issue. In addition, it focuses on the Malaysian legal provisions pertaining to mistake in contract law and also the issues of unfair contract terms. This paper adopts content analysis method where the materials used were largely library-based consisting of primary and secondary data. The primary data was gathered from case-law to explain how the legal principles are applied. English cases are the major references considering their high volume of cases on contractual issues. The secondary data was based on published materials, such as textbooks, journal articles, online databases and the Internet. For analysis, this paper applied a combination method of data analysis, namely, descriptive, critical and comparative approaches. The judges'statements in each case were examined carefully; highlighted loopholes, followed by rational justifications. The findings have established that notwithstanding the common law principle which recognises mistake as a vitiating factor in contract, the application of mistake as a defence in an advertisement containing price error
\end{abstract}


demonstrates divergent approaches by the courts. In addition, a review on the Malaysian legal framework pertaining to this issue reveals that due protection needs to be enhanced in order to warrant justice shall be served to a customer who has an unequal bargain.

Keywords: Contract, Mistake, Electronic advertisement, Unfair contract terms.

\section{INTRODUCTION}

Advertisement plays the most important role in business. It is the first step to promote industry in order to attract customer to purchase the goods. From contract law perspective, advertisement is an invitation to treat. Thus, when an owner advertises his products or goods, he is inviting customers to make an offer. An offer comes from a customer who orders the goods, and a contract will only be concluded once the owner accepted the customer's orders. This contractual principle governing the legal status of advertisement however will not be applied should certain factors are apparent from the advertisement that indicates otherwise. ${ }^{1}$ It should be noted that to a certain extent, an advertisement is no longer an invitation to treat but will amount to an offer.

Indeed, in constructing the wording of an advertisement, owners must be very careful since they shall be exclusively liable for its content. This trigger the question of what is the legal implication should the advertisement contains errors not noticed by the owners. In such incident, can the owners cancel the contract upon realising the mistake? This paper discusses the legal implications of such advertisement from contract law perspective in regards to an electronic advertisement containing price errors. In analyzing this issue, it begins with the discussion on the area of mistake in contract law and due regards have been referred to case-law decision which established the governing principle of law in this area. Furthermore, this paper highlights the common law and equitable approaches in dealing with this issue. Last but not least, this paper also focuses on the Malaysian legal provision pertaining to mistake in contract law and the issues of unfair contract terms. For legal analysis, a

See, Carlilv Carbolic Smoke Ball Co [1893] Q.B. 256 (C.A.). 
combination method of data analysis, namely, descriptive, critical and comparative approaches were used. The judges' statements in each case were examined carefully; highlighted loopholes, followed by rational justifications.

\section{Electronic advertisement in website and mistake of price}

With the current advancement of information technology (IT), many forms of business activities are easily transferrable into electronic versions. This includes the advertising of goods via electronic website using predominantly the Internet. The advertisement in this form is naturally more expedient and cost-effective, and has driven most, if not all business companies to be enthusiastic in advertising their products via on-line website. ${ }^{2}$ Unlike printed advertisements, in advertising through Internet, an advertiser should exercise extra care given the nature of the Internet, which is globally and easily accessible. Taking cue from this issue, any mistakes in wordings or statements of the advertisement shall trigger serious risk to the owner. In a worse case, the owner or the companies will be at total a loss since they are not only liable to customers within their jurisdiction but also expose to borderless claims from customers all over the world who read and order from their websites. ${ }^{3}$

The above scenario raises questions of legal issues in advertisements made via website, including the question of when a contract is deemed to conclude and mistakes that occur in advertisement. ${ }^{4}$

\section{Mistake in the law of contract}

Mistake is one of the defences in law of contract which vitiates the existence of a valid contract. English law recognises three (3) types of mistake in contract law. ${ }^{5}$ One is categorized as common mistake

There are two (2) different types of online advertisements; first, marketing materials on the businesses own website; secondly, advertisements on other websites (banner advertising; pop-ups; floating or expanding advertisements; sponsored content; pre-rolled videos before content on video sites).

3 It is beyond the scope of this paper to discuss on the issue of jurisdiction.

4 See, Partridge, K. (2014). From Post Box to Inbox: Serving Legal Notices by Email Property Law Bulletin.

5 Categories of mistake have been divided differently by authors, but majority of them rely on these traditional categories; see, Card \& James. (2016). Business Law for Business, Accounting \& Finance Students (3rd ed ed.). Oxford 
where both parties have made the same mistake. ${ }^{6}$ Two is a mutual mistake where both parties have made a mistake, but they have made a different mistake ${ }^{7}$ and thirdly, unilateral mistake where only one party is mistaken, and the other party knows, or can be taken to know, of the mistake. ${ }^{8}$ This paper focuses on the third type of mistake that is unilateral mistake with regards to electronic advertisement.

It is a trite principle of contract law that parties cannot easily discharged from their contractual duties based on the sole reason that they had signed a contract by mistake or misunderstanding, or had made a bad bargain. ${ }^{9}$ Consequently, common law offers strict limitation for mistake and contracting parties are bound by their agreement regardless of the mistake that they had made while signing the contract. As Lord Denning had highlighted in the case of Storer v Manchester City Council: ${ }^{10}$

In contract, you do not look into the actual intent in man's mind. You look at what he said and did.

Accordingly, contracting parties shall be bound by their words and conducts regardless of their intentions. However, it should be noted that common law allows a contract to be invalidated by unilateral mistake though such allowance permissibility is cautiously applied. It was established by Aikens J in Smith $v$ Hughes: ${ }^{11}$

The general rule at common law is that if one party has made a mistake as to the terms of the contract and that mistake is known to the other party, then the contract is not binding. The reasoning is that although the parties

University Press; Macdonald \& Ruth Atkins, Koffman \& Macdonald's. Law of Contract (8th ed.). Oxford University Press.

6 See, Bell v Lever Brothers Ltd [1982] A.C 161; Solle v Butcher [1950] 1 KB 671; Great Peace Shipping Ltd v Tsavliris Salvage; Associated Japanese Bank (International) Ltd v Crédit du Nord SA [1988] 3 All ER 902, [1989] 1 WLR 255A.

7 Sherwood v. Walker, 66 Mich. 568, 33 N.W. 919 (1887); Raffles v Wichelhaus (1864) 2 Hurl \& C 906 Court of Exchequer.

8 Tamplin v. James (1880) 15 Ch. D. 215; Smith v. Hughes (1871) L.R. 6 Q.B. 597

9 Clarion Ltd v National Provident Institution [2000] 2 All ER 265.

10 [174] 3 ALL ER 824:

11 (1871) L.R. 6 Q.B. 597 
appear, objectively, to have agreed terms, it is clear that they are not in agreement.

So should a mistake is made by one of the contracting parties and this mistake is known by the non-mistaken party, a contract will not binding as there is no consensus ad idem though both parties are deemed to agree with the terms of the contract.

\section{Unilateral mistake in website advertisement: Vitiating factor}

A unilateral mistake in electronic advertisement normally happens where the owner of the advertisement had mistakenly stated the price of the goods. Such mistake though vitiate the existence of a valid contract does not simply give leeway to a rescission. ${ }^{12}$

Notwithstanding the advance mode of the electronic advertisement, this method marked several incidents of price errors, which relatively caused big losses to companies albeit some of them were excluded from liabilities by virtue of their disclaimer clauses. All these while, the world had witnessed a number of episodes of price errors in electronic advertisement with appealing contractual legal issues. ${ }^{13}$ In 2002, Argos Company had advertised a television for £299.99 via their website. Unfortunately, by sheer mistake, the price was stated as £3. The advertisement was accessible all customers from all over the world. Within a few seconds, many customers had placed orders for the television. It was found that some customers had even ordered 1700 sets! $!^{14}$ Realizing their mistake, Argos wanted to cancel their advertisement by relying on the following arguments:

(1) It was a mistake in the price and mistake can be one of the defences in contract law, thus contract was void due to the mistake.

12 JC Smith in Bell v. Lever Bros Ltd. [1932] A.C. 161 (H.L.) At, 220-222 [Bell]; See Also, Cartwright, J. (2009). UNILATERAL MISTAKE IN THE ENGLISH COURTS: REASSERTING THE TRADITIONAL APPROACH: Statoil ASA v. Louis Dreyfus Energy Services LP (The" Harriette N"). Singapore Journal of Legal Studies, 226-234.

13 See, Rustad, M. L., \& D’Angelo, D. (2011). The path of internet law: an annotated guide to legal landmarks. Duke L. \& Tech. Rev., 1. Retrieved April from http:// scholarship.law.duke.edu/cgi/viewcontent.cgi?article=1226\& context=dltr

14 The Company file 'Online’ row over $£ 3$ TVs [Business]. (1999, September 8). Retrieved April 8, 2017, from http://news.bbc.co.uk/2/hi/business/441426.stm. 
(2) As an owner of the advertisement, they had a right to rely on the term that an advertiser had a right to cancel or amend any wording of the advertisement.

(3) Advertisement is an invitation to treat and not an offer. Thus, when the customer placed their orders, it is an offer from customers and no contract had been concluded. ${ }^{15}$

This incident had naturally resulted in chaos in England, which had lawyers and legal experts critically propounding their critical views. The following points had been submitted to contend Argos's arguments:

(1) Argos could not use mistake as a defence since the advertisement had taken place during Boxing Day sale, a day which is widely known to be the day where all goods are sold at rock bottom prices. Any reasonable man may think that the price stated in the advertisement was for real.

(2) Relying on the term that the advertiser had a right to cancel, or amend any parts of the advertisement was not allowed since the essence of this term itself contradicts the provision of the Unfair Terms in Consumer Contracts Regulation. This regulation invalidates any terms that are "unfair" or lacking in good faith and which creates an imbalance between the parties. Accordingly, any cancellation or amendment, which is appears to be unfair to any contracting party, shall be invalidated. ${ }^{16}$ To cancel the price at the very last minute was deemed to be unfair to customers who had already placed their orders.

(3) Whilst an advertisement on its own is merely an invitation to treat but consequently when the customer clicks the 'send' button to place his order, an offer is constituted. The almost instantaneous automated response from Argos further acknowledged the order and promised the customer that the order shall be delivered within prescribed period. It appears that a contract was duly completed since the automated response indicates acceptance from the owner. ${ }^{17}$

15 Rogers, K. M. (2002). Snap! Internet' Offers' under Scrutiny Again. Business Law Review, 23(3), 70-72.

16 See, The Unfair Contract Terms Act 1977, section 17, see also, the Unfair Terms in Consumer Contracts Regulations 1999, Regulation 5(1).

17 In contrast, see, Corinthian Pharmaceutical Systems Inc v. Lederie Laboratories, 724 F. Supp. 605, 1989 U.S. Dist. 13058 where an automated response by an 
At the end of the day, Argos surrendered and honoured all the orders. The similar incident happened to Kodak where the price of camera worth $£ 329$ was stated as $£ 100 .{ }^{18}$ Similarly to like Argos, Kodak had changed the figure immediately upon realizing their mistake. Initially Kodak refused to honour their purported promise but later took the same step as Argos and delivered all the orders. In both cases they did it without prejudice and as a gesture of good faith rather than on the basis of the contract. It was established from both incidents that Argos and Kodak illustrate good examples of business ethics where both companies had admitted their mistakes and took responsibility to settle the case amicably. On one hand, they appeared to be the losing parties but on the other hand, they secured customers' confidence in their ethical policy. ${ }^{19}$ However, these two cases were not brought before the court; otherwise, firm legal principles could have been clearly established on these issues.

Another similar incident took place in 2003, where experienced online retailer Amazon.com had mistakenly advertised a television for USD 99.99 where the actual price was USD 1049. ${ }^{20}$ Upon detecting the price error, Amazon.com purported to cancel 6,000 orders for the television. Amazon.com would have borne the risk of loss amounting to over $\$ 500,000$, but fortunately, unlike the previous companies, it successfully relied on the advantage designed by its user interface for online contracting which minimized the company's exposure to this kind of risk. Thus, Amazon.com was protected from significant loss by being able to cancel the orders. It was ruled by King County District Court Judge Eileen Kato that Amazon.com was not liable to honour customers' orders since they were yet to complete the charge on customers' credit card and therefore the sale was never

order-tracking system stating an order-tracking number was held to be merely an acknowledgment of the order and not an acceptance of the offer.

18 Bates, D. (2002, March/April). Mistakes in Online Transactions - The Lessons to Be Learned from Kodak. Internet Newsletter for Lawyers. Retrieved April 2, 2017, from http://ssrn.com/abstract=2307459 orhttp://dx.doi.org/10.2139/ ssrn.2307459.

19 Lawrence H. Hertz, L. H. (2002). Kodak suffered a loss of more than £2 million,', Don't Get Trapped into Honoring Online Pricing Errors!, E-Com. L. Rep,4(7), 6th ser.; Groebner, B. (2004). Oops-The Legal Consequences of and Solutions to Online Pricing Errors. Shidler JL Com. \& Tech., 1, 1.

20 Groebner, B. (2004)., ibid. 
concluded. ${ }^{21}$ The pricing policy stated in its website served as a good disclaimer to Amazon.com and granted the discretion to deal with each sale on a case-by-case basis. Therefore, Amazon.com neither had to honour the orders nor compensate their customers.

Other similar instance occurred in 1999, where Buy.com advertised a \$588 Hitachi computer monitor on its site for $\$ 164 . .^{22}$ Based on marketing slogan 'lowest prices on Earth,' Buy.com began taking the orders. Upon realizing the price error, Buy.com prompted to sell only what it had in stock on hand on a first-come, first-served basis for the 143 monitors. Though purchase confirmations were delivered to some customers and their credit cards were charged, the company canceled the other orders. About 7000 customers brought legal action against Buy.com to honour the orders. The court approved Buy.com's terms of settlement that apart from legal expenses, they must pay out around $\$ 60$ for each customer totaling about $\$ 400,000$. Thus, the company is saved since it can implement inexpensive measures to protect against this type of loss.

A decision on unilateral mistake in electronic advertisement, containing an insightful legal principle, took place in the Singaporean case of Chwee Kin Keong and Ors v Digilandmall.Com Pte Ltd. ${ }^{23}$ In this case; the defendant company had mistakenly advertised HD Laser printer for $\$ 66$ where the actual price was $\$ 3854$. Upon realizing the gross mistake, the defendant company immediately invalidated the contract. They argued that their unilateral mistake was genuine and should reasonably be realized by the plaintiff. Denying their awareness, the plaintiffs insisted the defendant company to honour their orders. The plaintiffs also argued that if the contracts concerned were not enforced upon the application of the doctrine of mistake, undesirable uncertainty would prevail in commercial transactions, especially over the Internet. ${ }^{24}$

21 Heckman, C. (2003, January 28). 'A 36-inch TV just \$99? Judge sees the big picture Court rules customer a victim only of price error by Amazon' Seattle Post-Intelligencer. Seattle Post-Intelligencer.

22 Tedeschi, B. (1999, December 13). Pricing Errors On The Web Can Be Costly'. New York Times. Retrieved October 11, 2017, from http://movies2. nytimes.com/1999/12/13/technology/13commerce.html

23 [2005] 1 S.L.R. 502 (C.A.). Hereinafter will be referred to as Digilandmall's case

24 Phang, A. (2005). Vitiating Factors in Contract Law-Some Key Concepts and Developments. SAcLJ, 17, 148. 
In the High Court, Rajah JC rejected the plaintiff's argument and gave the judgment in favour of the defendant company. The judge held that the doctrine of unilateral mistake had vitiated the contracts, which were concluded between the plaintiffs and the defendant. Furthermore, the judge pointed out that the contracts could be rescinded since it was established that the plaintiffs had a constructive knowledge of the price errors. The decision was affirmed by the Court of Appeal where the mistake in the price of the laser printer was acceptable as a defence to invalidate the contract executed via website. ${ }^{25}$ Relying on the background of the plaintiffs, the court viewed that they could be in a position of having knowledge of the mistake of the price and had taken advantage of the defendant's mistake. The facts proven as the plaintiffs who were conversant in such industry might be expected to know that the price was very low and not reasonable. Chao Hick Tin JA in delivering the judgment highlighted that:

From these exchanges between the first appellant and Desmond, the former knew that the offer of $\$ 66$ per printer was too good to be true and that it must have been a mistake. The first appellant wanted to buy more to make more easy money. He even asked Desmond why the latter only bought three printers. Eventually, when the first appellant managed to obtain access into the HP Website, he placed an order for 100 printers. We agree with the trial judge when he held that the first appellant was "fully aware of the likely existence of an error." The first appellant is no longer appealing against the decision of the judge in holding that the contract was void for unilateral mistake, and is only appealing against certain orders on costs. ${ }^{26}$

It was emphasized that the existence of mistake shall not simply vitiate the contracts; but such mistake must be sufficiently fundamental on the terms of the contract affecting the consent of the mistaken party. In the present case, it was viewed that the error in the price is fundamental. ${ }^{27}$ However, the judge reserved to elaborate on what if the non-mistaken party or the plaintiffs in this case were bona fide and had a valid reason to believe that the price is correct.

\footnotetext{
[2005] SGCA 2 (C.A.).

26 [2005] SGCA 2 (C.A.), Chao Hick Tin JA, Para 11.

27 Ibid, para 34.
} 
Comparatively, the above case was different with Argos and Kodak as in those cases; both advertisements had taken place during Boxing Day where it is normal that all items are sold in the lowest prices. The question of actual and constructive knowledge seems to be no longer relevant in such condition since it is reasonable for customers to assume or believe that the items were sold at crazy prices. In such cases, the questions of fairness might be worth considered as it would be inequitable for the bona fide customers who innocently relied on the advertisement to be frustrated by the result of contract been invalidated. A fortiori, the mistaken party in such cases shall be liable of such mistake which would no occur had reasonable care was exercised before launching their advertisement via website.

\section{Price mistake in Digilandmall's case - evidential aspect}

The decision in Digilandmall had clearly established the two (2) main criteria that must be fulfilled by the mistaken party in order to enable him to invalidate the contract. First, fundamentality where it is crucial to prove that the mistake is fundamental and relate to an essential term thus vitiating consent of the mistaken party to enter into a contract. ${ }^{28}$ In the event that the mistake is not fundamental, the contract would not be declared as void. The judge pointed out the following remark in regards to this:

As the law now stands, mistakes that are not fundamental, or which do not relate to an essential term, do not vitiate consent. ${ }^{29}$

The above criteria contradicted the conclusion derived by Treitel while referring to the facts of Smith $v$ Hughes; where the author states:

Mistakes as to the person and mistakes as to the subject matter negative consent only if they are fundamental. There seems to be no such requirement where the mistake is as to the terms of the contract. ${ }^{30}$

28 Phang, A. (2005). Vitiating Factors in Contract Law-Some Key Concepts and Developments. SAcLJ, 17, 148.

29 Chwee Kin Keong v Digilandmall.com Pte Ltd [2005] 1 SLR 502 Rajah JC, at p 32.

30 Peel, E. (2015). Treitel on the Law of Contract (Vol. 414). London: Sweet \& Maxwell. 
Hence, it is uncertain whether Digilandmall either consciously or unconsciously changed the principle ruled out from Smith $v$ Hughes, ${ }^{31}$ which had waived the requirement of fundamental should the mistake is relating to the terms of the contract. In Smith's case, it was decided that a mistake as to a term of the contract negatives consent although the term relates to a quality of the subject matter which is not fundamental. ${ }^{32}$

The second criterion is knowledge. Common law entitles the mistaken party to invalidate the contract should the existence of the actual knowledge on the non-mistaken party could be proven. The court elaborates that a process of reasoning or what is referred to as "Nelsonian Knowledge" could test the existence of actual knowledge; where a reasonable person in that similar situation would have known:

In this connection, we would refer to what is called "Nelsonian knowledge", namely, wilful blindness or shutting one's eyes to the obvious. Clearly, if the court finds that the non-mistaken party is guilty of wilful blindness, it will be in line with logic and reason to hold that that party had actual knowledge. ${ }^{33}$

It is observed that the decision is in compliance with the common law approach in the case of Harrison $v$ Halliwell Landau, ${ }^{34}$ where the judge Eccles QC stated that:

To set aside a contract for unilateral mistake, it was not sufficient for the claimant to prove that he was mistaken in an important matter. He must go further and establish that the other contracting party contributed to the mistake or consciously took advantage of the mistake in a way and to a degree

\footnotetext{
31 (1871) L.R. 6 Q.B. 597.

32 In Smith's case, the buyer had mistakenly thought the oats that he bought for his trained horse; by sample were old, but it was actually new oats. He later refused to accept the delivery of the new oats, which were of no use to him. The seller sued for the price. It was submitted that if the buyer did believe the oats to have been warranted old, and the seller knew this, the buyer could have been excluded from liability on an alternative ground.

33 Digilandmall, at para 42.

34 2004] EWHC 1316 (QB), [2004] All ER (D) 374 (May)
} 
that would make it inequitable for that other party to enforce the contract.

Along the similar vein, the Court of Appeal in Digilandmall, by relying on the equitable approach, had broadened this scope of actual knowledge and recognized constructive knowledge as another important factor to invalidate the contract with a unilateral mistake. Indeed, there must be a mistaken assumption on the part of the nonmistaken party to the contract. It was highlighted:

However, there is an exception to this rule when the offeree knows that the offeror does not intend the terms of the offer to be the natural meaning of the words: see Shogun Finance Ltd v Hudson [2004] 1 AC 919 ("Shogun Finance") at [123] and Hartog v Colin \& Shields [1939] 3 All ER 566 ("Hartog"). The reason behind this exception is self-evident, as a party who is aware of the error made by the other party cannot claim that there is consensus ad idem. The law should not go to the aid of a party who knows that the objective appearance does not correspond with reality. It would go against the grain of justice if the law were to deem the mistaken party bound by such a contract. ${ }^{35}$

This issue of website pricing errors is simplified by one author by depending on a matter of degree. ${ }^{36}$ In a unilateral mistake case, if a bona fide buyer is an ultimate user for the goods that he bought, he may be excluded from liability of 'snapping up. ${ }^{37}$ On the other hand, the court will tend to activate the existence of actual or constructive knowledge in 'mass mistake' case and invalidating the contract. ${ }^{38}$

The decision in Digilandmall is yet to be challenged. However, a similar issue happened in a more recent case in US, Burkhart v. Wolf Motors of Naperville, Inc. ${ }^{39}$ The defendant, Wolf Motor, had

\footnotetext{
35 Digilandmall, at para 31.

36 Leng, T. K. (2004). Who bears the risk of mistake? Computer Law \& Security Report, 20(5), 396-399.

37 A non-mistaken party had taken advantage of a known mistake by a mistaken party before the mistaken party realize the mistake and rectify or changes his mind about entering into the contract; Ibid, at 397.

38 Ibid.

392016 IL App (2d) 151053.
} 
advertised a Toyota at a price $\$ 19,9991$ where the actual price was $\$ 39,9991$. The mistake was caused by a new trainee and upon realizing the mistake, he immediately amended the price without knowing that it took about four days for the system to update the website. The plaintiff, after testing the car agreed to buy it but the defendant explained that the price was a mistake and offered to reduce it to $\$ 35,000$. The plaintiff refused to accept the adjustment price and claimed that the defendant had breached the contract. In addition, the plaintiff alleged that the defendant had committed fraud by making the customer relying on the deceptive price in the advertisement while the defendant did not intend to sell it at the advertised price; thus breach of contract and violation of the Illinois Consumer Fraud and Deceptive Business Practices Act (Act) (815 ILCS 505/2 (West 2014)). In rejecting the plaintiff's claim, the trial court held that there was no contract exists between the parties due to the absence of mutual assent, as the "plaintiff believed she was purchasing a car for $\$ 19,991$ [while] the defendant's salesman believed he was selling the same car for $\$ 36,991 .{ }^{\prime \prime 4}$ In addition, the trial court dismissed the plaintiff's claim of consumer fraud on the part of the defendant since the defendant has no such intention to make the plaintiff relied on the deceptive price. ${ }^{41}$

On appeal, the Appeal Court highlighted that to establish his claim based on Illinois Consumer Fraud and Deceptive Business Practices Act, a plaintiff must prove: "(1) a deceptive act or practice by the defendant, (2) the defendant's intent that the plaintiff rely on the deception, (3) the occurrence of the deception in a course of conduct involving trade or commerce, and (4) actual damage to the plaintiff that is (5) a result of the deception." 42

Plaintiff failed to prove all the requirements. The most obvious ground for rejection is the plaintiff suffered no actual damage due to the defendant's deceptive advertisement.

Generally, to allege the existence of deceptive intention on the part of the defendant advertiser is not a good ground for the plaintiff to obtain a judgement. Indeed, it is challenging to prove the existence of fraud as its existence demands a higher standard of proof. Otherwise, the claim of fraud existence remains a mere allegation.

40 ibid, para 9.

41262 N.E.2d 758, 128 Ill. App. 2d 410 (App. Ct. 1970.

42 ibid, para 21. 


\section{Mistake in Electronic Advertisement - Malaysian Legal Provisions}

In Malaysia, the incident of mistake of price in the advertisement or website is yet to be reported by case law. However, the legal provisions pertaining to the issues of mistake in a contract are expressly provided by sections 21 (mistake of fact), 22 (mistake of law applicable in Malaysia) and 23 (mistake by one party) of the Contracts Act 1950 (Act 130). Among these provisions, section 21 is the most relevant to the issue discussed in this paper. This section enacts as follows:

Where both the parties to an agreement are under a mistake as to a matter of fact essential to the agreement, the agreement is void.

Pursuant to this provision, the contract shall be void should there is a mistake of fact essential to the agreement. Therefore, by implication, a mistake as to the price stated in the online advertisement can be considered as essential since it is the mistake in regards to the subject matter of the contract. This type of mistake shall invalidate the contract should the contract has been executed between the advertiser and the customer.

Section 21 has been referred to in the local case of Tan Chin Swee \& Anor v. Seri Ampangan Realty $S d n$ Bhd ${ }^{43}$ where the judge highlighted:

I will now say something about the mistake as to the subject matter of the contract. Mutual mistake arises where the parties are at cross-purposes as to the subject matter of the contract. That being the case, there is no genuine agreement despite appearances. Put in another way, where one party intends to sell one thing and the other party intends to buy something different; or where one party intends to contract on one set of terms and the other intends to deal on a different set of terms such cross-purposes are known as mutual

43 High Court Malaya, Kuala Lumpur [Originating Summons No: S4-24-19862003,24 January 2005], 
mistake. It arises where the parties are mistaken as to each other's intention. ${ }^{44}$

Furthermore, the judge quoted section 10(1) of the Contracts Act 1950 enacts as follows:

All agreements are contracts if they are made by the free consent of parties competent to contract, for a lawful consideration and with a lawful object, and are not hereby expressly declared to be void.

The Act signifies that consent occurs where two or more persons agree upon the same thing in the same sense. ${ }^{45}$ This consent is said to be free as long as it is not vitiated by any of the elements mentioned in section 14 of the Contracts Act 1950 that can make the contract voidable. Those elements are coercion (section 15), undue influence (section 16), fraud (section 17), misrepresentation (section 18) and mistake (sections 21, 22 and 22).

The judge in Tan Chin Swee above had also referred to the case of Tham Kong v. Oh Hiam \& Ors, ${ }^{46}$ where Barakbah LP made the following statement in regards to section 21 of the Contracts Act 1950:

According to section 21 of the Contracts (Malay States) Ordinance, 1950, where both the parties to an agreement are under a mistake as to a matter of fact essential to the agreement, the agreement is void. Mistakes may be classified into: (1) common mistake; (2) mutual mistake; and (3) unilateral mistake. Mistake is common where both parties make the same mistake. Each knows the intention of the other and accepts it, but each is mistaken about some underlying and fundamental fact. The mistake is mutual where the parties misunderstand each other and are at cross-purposes. In unilateral mistake only one of the parties suffers from some mistake. ${ }^{47}$

Thus, it obvious that the mutual mistake by both parties renders the contract void. Unlike the UK provisions which offer a strong customer shield through their Unfair Contract Terms Act 1977,

\footnotetext{
44 Tan Chin Swee \& Anor v. Seri Ampangan Realty Sdn Bhd, High Court Malaya, Kuala Lumpur [Originating Summons No: S4-24-1986-2003,24 January 2005], per Abdul Malik Ishak J, at 870.

45 Section 13, Contracts Act 1950.

$46 \quad$ [1968] 1 MLJ 44, FC.

47 Ibid, at 45 .
} 
Malaysia is still lacking for the similar protection. However, by virtue of the latest amendment of the Consumer Protection Act 1999 in 2010 , the gap is deemed to be closed although not entirely. The new amendment of The Consumer Protection (Amendment) Act 2010 (Malaysia), which adopted the Indian Law Commission Report on Unfair (Procedural \& Substantive) Terms in Contract (2006), added a new Part IIIA entitled 'Unfair Contract Terms.' This new part offers some safeguards which are akin to the UK Unfair Contract Terms. Based on section 12(1), a person commits an offence:

(a) if he gives to a consumer an indication which is misleading as to the price at which any goods or services are available; or

(b) if an indication given by him to a consumer as to the price at which any goods or services are available becomes misleading and he fails to take reasonable steps to prevent the consumer from relying on the indication.

(2) For the purposes of subsection (1), it shall be immaterial(a) whether the person who gives the indication is acting on his own behalf or on behalf of another; (b) whether or not the person who gives the indication is the person or included among the persons from whom the goods or services are available; (c) whether the indication is or becomes misleading in relation to all the consumers to whom it is given or only in relation to some of them.

Apart from the above, the general procedural unfairness is provided by section $24 \mathrm{C}$.

(1) A contract or a term of a contract is procedurally unfair if it has resulted in an unjust advantage to the supplier or unjust disadvantage to the consumer on account of the conduct of the supplier or the manner in which or circumstances under which the contract or the term of the contract has been entered into or has been arrived at by the consumer and supplier.

The protections offered by the above provisions, however, cover consumer contract and not extended to a commercial contract. ${ }^{48}$

48 Trakic, A. (2015). Statutory protection of Malaysian consumers against unfair contract terms: Has enough been done? Common Law World Review, 44(3), 203221. See also, Amin, N. (2013). Protecting consumers against unfair contract terms in Malaysia: the Consumer Protection (Amendment) Act 2010. Malayan Law Journal, 1, 1-11. 
It is claimed that the provisions of Part III are limited and vague triggering legal issues of interpretation. For instance, the provision that an unfair term must cause 'significance imbalance' to the rights and obligation of the contracting parties to the detriment of the consumer ${ }^{49}$ However, the act is silent of what are the circumstances amounting to significance imbalance. This loophole is left to the tribunal or court to come up with interpretation. Furthermore, the tribunal claims are only limited to consumer claims amounting to RM25000 only. Thus, any claim exceeded this amount will be excluded.

Therefore, in order to enhance customers' protection and clarify any legal issues pertaining to the unfair contract terms, it is proper for Malaysia to come up with one exclusive act on the Unfair Contract Terms rather than attached it under the Consumer Protection Act 1999. This is to fulfil the demand that the same protection should also be given to the unfair contract term issues under contract law considering the fact that the Contract Act 1950 has done nothing to offer such protection to the contracting party who has unequal bargaining power. In addition, Malaysia, unlike its neighbouring countries who have already equipped with such legal protection, has left behind in regards to the legal framework governing protections of the unfair contract terms. ${ }^{50}$

\section{Protective measures: Can disclaimer protect the mistaken party?}

Due to the potential risk that owners may possibly encounter in online advertisements, it is prudent to secure their position by highlighting clear wordings to the content of the advertisement and have them backed up by a disclaimer. The liability of the owner may accordingly depend on what the disclaimer states.

On one hand, it is to be noted that the bottom line of the owner's liability is about offer and acceptance. If an owner designs the website to make it clear that a purchase that a customer makes amount to merely an offer, and any acknowledgement of an order is simply constituting an offer not amounting to an acceptance; the owner's liability shall by all means, be excluded. This can be illustrated by the wordings used by the Amazon terms:

49 Trackic, ibid, at 209-210.

50 Trackic, 208. 
Your order is an offer to Amazon to buy the product(s) in your order. When you place an order to purchase a product from Amazon, we will send you a message confirming receipt of your order and containing the details of your order (the Order Confirmation"). If you are using certain Amazon Services (e.g. Amazon mobile applications) the Order Confirmation may be posted on a Message Centre on the website. The Order Confirmation is acknowledgement that we have received your order, and does not confirm acceptance of your offer to buy the product(s) or the services ordered. We only accept your offer, and conclude the contract of sale for a product ordered by you, when we dispatch the product to you and send e-mail or post a message on the Message Centre of the website confirming to you that we've dispatched the product to you (the "Dispatch Confirmation"). If your order is dispatched in more than one package, you may receive a separate Dispatch Confirmation for each package, and each Dispatch Confirmation and corresponding dispatch will conclude a separate contract of sale between us for the product(s) specified in that Dispatch Confirmation.

The above wordings are clearly about offer and acceptance, which expressly connotes that there will be no legal duty to honour. Therefore, if at the first instance, an owner can highlight or clarify the wordings of his advertisement, which does not offer any rooms for ambiguities, his position will be secured and potentially preclude him from possible legal suits from customers.

\section{CONCLUSION}

In the case of unilateral mistakes of price errors by mistaken party in website advertisement, common law grants the mistaken party a right to invalidate the contract if it could be established that another party has actual knowledge of the existence of the mistake. This principle had been broadened by equity where a constructive knowledge on the part of the non-mistaken party can be a good ground to set aside the contract. Nevertheless, equity justifies the rescission of contract 
only if the mistake is fundamental and if the non-mistaken party had a reason to believe that the term is incorrect.

Equitably, the law relating to unilateral mistake shall not be applicable to protect an unscrupulous non-mistaken party; meanwhile the opportunity for the mistaken party to invoke the legal protection depends on the degree of knowledge of the non-mistaken party. If it could be established from the facts of the case that the actual and constructive knowledge are apparent on the part of the latter, the former's right to invalidate the contract would remain.

Therefore, it is advisable for companies who wish to advertise their products via website to exercise due care and precaution since their negligence in designing the presentation or wording of their advertisements may trigger legal repercussion. Apart from that, the companies must make sure that their websites are equipped with disclaimers or a system, which can be reliable in serving protective measures should they suffer any claims from customers. Otherwise, there is a possibility of total loss on the part of the mistaken companies who are stranded in the unnecessary trivial price mistake!

\section{ACKNOWLEDGEMENTS}

This work was supported by the Sabbatical Grant, 2016, University Malaya. The author gratefully acknowledges the use of service and facilities of the Hallward Library, University of Nottingham, United Kingdom. Special thanks are due to my advisor during my sabbatical leave at the University of Nottingham, Associate Professor Dr Richard Hyde, School of Law and Social Sciences, University of Nottingham, for his very constructive comments in the earlier draft of this paper.

\section{REFERENCES}

Abbiati, P. (2001). Let the e-buyer beware. Supply Management, 4343.

Amin, N. (2013). Protecting consumers against unfair contract terms in Malaysia: The Consumer Protection (Amendment) Act 2010. Malayan Law Journal, 1, 1-11. 
Associated Japanese Bank (International) Ltd v Crédit du Nord SA [1988] 3 All ER 902, [1989]

1 WLR 255A.

Bell v Lever Brothers Ltd [1982] A.C 161; Solle v Butcher [1950] $1 \mathrm{~KB} 671$

Bell v. Lever Bros Ltd. [1932] A.C. 161 (H.L.) At, 220-222 [Bell]

Carlil v Carbolic Smoke Ball Co [1893] Q.B. 256 (C.A.).

Cartwright, J. (2009). Unilateral mistake in the English courts:

Reasserting the traditional approach: Statoil ASA v. Louis

Dreyfus Energy Services LP (The" Harriette N"). Singapore Journal of Legal Studies, 226-234.

Centrovincial Estates v Merchant Investors Assurance Co Ltd [1983] Com LR 158.

Clarion Ltd v National Provident Institution [2000] 2 All. E.R. 265

Contract Act 1950 (Act 136)

Consumer Protection Act 1999 (Act 599)

Corinthian Pharmaceutical Systems Inc v. Lederie Laboratories, 724 F. Supp. 605, 1989 U.S. Dist. 13058

Great Peace Shipping Ltd v Tsavliris Salvage [2002] EWCA Civ 1407

Groebner, B. (2004). Oops-The Legal Consequences of and Solutions to Online Pricing Errors. Shidler JL Com. \& Tech., 1, 1.

Hertz, L. H. (2002). Don't Get Trapped into Honoring Online Pricing Errors! E-Com. L. Rep.6

Hartog v Colin \& Shields [1939] 3 ALL ER 566

Leng, T. K. (2004). Who bears the risk of mistake? Computer Law \& Security Report, 20(5),

396-399.

Macdonald, E., Atkins, R., \& Atkins, R. D. (2014). Koffman \& Macdonald's Law of Contract. Oxford University Press, USA.

Partridge, K. (2014). From post box to inbox: Serving legal notices by email Property Law Bulletin.

Phang, A. (2005). Vitiating factors in contract law-some key concepts and developments. SAcLJ, 17, 148.

Raffles $v$ Wichelhaus (1864) 2 Hurl \& C 906 Court of Exchequer.

Roach, L. (2016). Card and James'business law. Oxford University Press.

Rustad, M. L., \& D'Angelo, D. (2011). The path of internet law: an annotated guide to legal landmarks. Duke L. \& Tech. Rev., 1 .

Sherwood v. Walker, 66 Mich. 568, 33 N.W. 919 (1887) 
Smith v. Hughes (1871) L.R. 6 Q.B. 597 [Originating Summons No: S4-24-1986-2003,24 January 2005],

Tamplin v. James (1880) 15 Ch. D. 215

Tan Chin Swee \& Anor v. Seri Ampangan Realty Sdn Bhd, High Court Malaya, Kuala Lumpur

Tedeschi, B. (1999, December 13). Pricing errors on the web can be costly. New York Times. Retrieved July 5, 2016.

Trakic, A. (2015). Statutory protection of Malaysian consumers against unfair contract terms: Has enough been done? Common Law World Review, 44(3), 203-221.

Tham Kong v. Oh Hiam \& Ors [1968] 1 MLJ 44, FC. 